\title{
Multiple brown tumors of the orbital walls: case report
}

\author{
Tumor marrom múltiplo das paredes orbitárias: relato de caso
}

Mário Luiz Ribeiro Monteiro ${ }^{1}$

Trabalho realizado no Departamento de Oftalmologia da Universidade de São Paulo - USP- São Paulo (SP) Brasil.

${ }^{1}$ Professor Associado, Livre Docente da Divisão de Clínica Oftalmológica da Faculdade de Medicina da Universidade de São Paulo - USP - São Paulo (SP) - Brasil

Corresponding author: Mário Luiz R. Monteiro. Av. Angélica, 1.757 - Conj. 61 - São Paulo (SP) CEP 01227-200

E-mail: mlrmonteiro@terra.com.br

Recebido para publicação em 13.01.2008

Última versão recebida em 17.07.2008

Aprovação em 30.11.2008

\begin{tabular}{|l|}
\hline ABSTRACT \\
\hline We report the case of a 40-year-old woman with chronic renal failure and \\
secondary hyperparathyroidism that presented with slowly progressive \\
proptosis of the right eye and mass sensation in the temporal and frontal \\
orbital margins. Computerized tomography scan revealed two separate \\
hyperdense and well-circumscribed lesions in the right orbital walls. A \\
biopsy followed by histopathologic study revealed a dense lesion, with \\
fibrous proliferation associated with osseous metaplasia and osteoclastic \\
activity in the tumor, compatible with the diagnosis of brown tumor. The \\
patient was submitted to surgical removal of the parathyroid glands that \\
resulted in marked improvement in her condition and regression of the \\
orbital tumors. Although the occurrence of more than one separate bone \\
lesion in the orbit usually suggests metastasis, our case shows that brown \\
tumors should also be included in the differential diagnosis of such \\
lesions, particularly in patients with hyperparathyroidism. \\
\hline
\end{tabular}

Keywords: Hyperparathyroidism, secondary; Kidney failure, chronic/complications; Orbital neoplasms; Exophthalmos/etiology; Vision disorders/etiology; Diagnosis, differential; Case reports [Publication type]

\section{INTRODUCTION}

Brown tumors represent localized bony accumulations of fibrous tissue and giant cells that can occur in patients with primary and secondary hyperparathyroidism. They appear as well-defined lesions of the skeleton most commonly in the ribs, clavicle, pelvic girdle and mandible. Only 16 such cases have been reported in the orbit and all of them presented as single lesions ${ }^{(1-6)}$. The purpose of this paper is to report one patient with secondary hyperparathyroidism that presented with two separate hyperdense lesions in the right orbit suggesting metastatic tumors confirmed to be brown tumors, and to review the differential diagnosis of this condition.

\section{CASE REPORT}

A 40-year-old woman with chronic renal failure secondary to hypertension complained of slowly progressive right-sided proptosis of approximately two-year duration. Six months prior to our examination, proptosis became more prominent and was associated with right-sided tearing and frontotemporal pain. She had been on hemodialysis treatment for 7 years and had secondary hyperparathyroidism. She was taking calcium supplements and antihypertensive medications.

On examination her best corrected visual acuity was $20 / 20$ in the right eye (OD) and 20/30 in the left (OS). There was $6 \mathrm{~mm}$ of proptosis and downward deviation of the OD (Figure 1). Upgaze and right gaze were moderately 
restricted. Slit lamp examination, pupillary reactions and intraocular pressure measurements were normal. Fundus examination revealed marked atherosclerotic changes of the vessels in both eyes more prominent in OS. A firm, nontender mass was present in the right superolateral orbit and another one in the middle of the frontal bone, reaching the orbital rim. A computerized tomography scan showed two separate mostly hyperdense and well-circumscribed lesions in the right orbit. Both lesions were heterogeneous with hyperdense areas intermingled with some normal or hypodense areas. The lateral wall lesion was very large, with partial erosion of its lateral and medial limits extending medially to the orbit and laterally to the temporal fossa (Figure 2). A biopsy was performed through a lateral skin incision revealing a firm and multilobular tumor. Histopathologic examination revealed a tumor composed of a uniform distribution of multinucleated giant cells in a background of fibrovascular proliferation. There was fibrous proliferation associated with osseous metaplasia and osteoclastic activity in the tumor. The diagnosis

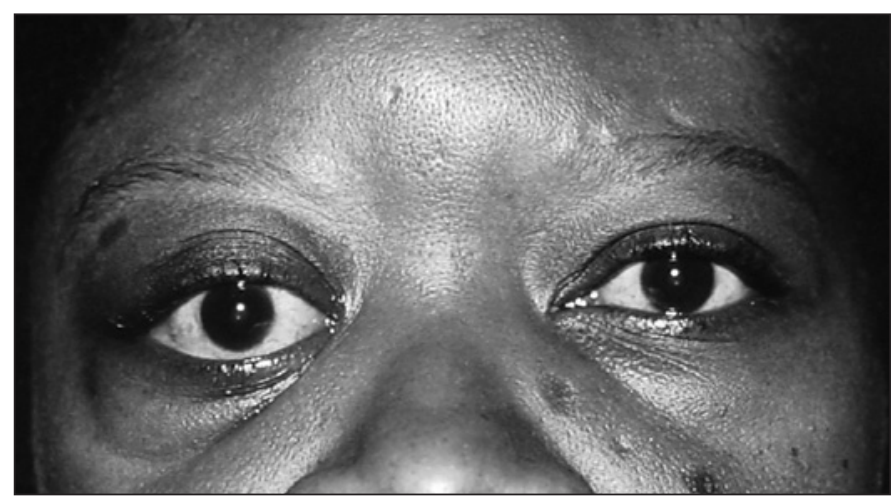

Figure 1 - External photograph of the patient showing right-sided proptosis and slight downward deviation of the right eye

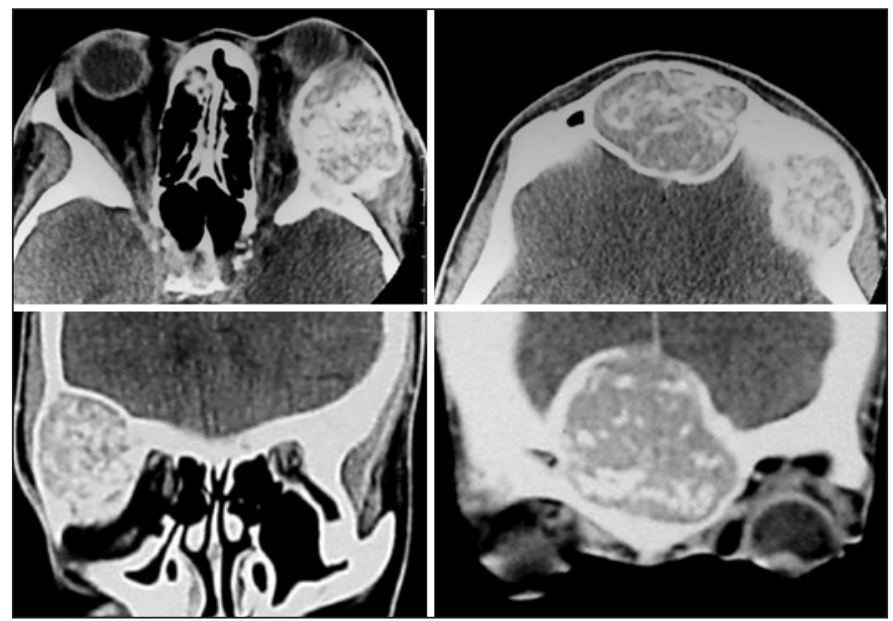

Figure 2 - Computerized tomography scan on axial cuts (above), and coronal cuts (below) showing one lesion in the frontal bone reaching the superior right orbital rim (right), separated from a second lesion involving the lateral orbital wall (left) was consistent with brown tumor. In order to control the hyperparathyroidism, the patient was submitted to surgical removal of the parathyroid glands with marked improvement in her condition. The orbital lesions progressively reduced in size and the pain disappeared. There was marked regression in the proptosis of the right eye.

\section{DISCUSSION}

Chronic renal failure results in decreased phosphate excretion, hyperphosphatemia and hypocalcemia. These factors lead to stimulation of the parathyroid glands. Elevated levels of parathormone affect bone causing conversion of potentially osteogenic cells from osteoblasts to osteoclasts. Osteoid is elaborated within a vascular fibroblastic tissue with abortive attempts at bony trabecula formation. Cysts may develop as a result of bleeding and tissue degeneration. Giant cell masses or brown tumors may result from these changes and are usually seen as focal bony lesions.

Patients with brown tumors in the orbit may have a mass, proptosis, pain, diplopia, decreased extraocular motility or decreased visual acuity. Radiologic studies usually show a moth-eaten appearance of bony demineralization with erosion of the inner and outer cortical layers and fractures.

When brown tumor occurs as a single lesion in the orbit, the differential diagnosis will include giant-cell tumor, giant-cell reparative granulomas, aneurismal bone cyst, fibrous displasia, osteoblastoma and metastasis ${ }^{(1-2)}$. The presence of more than one separated lesion would exclude most of these conditions and suggests metastasis. Our case shows, however, that brown tumors should also be considered in the diagnosis even when more than one lesion is present in the orbital region.

\section{RESUMO}

Este trabalho relata o caso de uma paciente de 40 anos, com insuficiência renal crônica e hiperparatireoidismo secundário que se apresentou com proptose progressiva e tumoração nas regiões lateral da órbita e superior da órbita. Tomografia computadorizada revelou duas lesões ósseas separadas, bem delimitadas e hiperdensas nas paredes orbitárias. Uma biópsia seguida de estudo histopatológico revelou um tumor denso, com proliferação fibrosa associada a metaplasia óssea e atividade osteoclástica no tumor, características compatíveis com tumor marrom. A paciente foi submetida a remoção das glândulas paratiróides que resultou em melhora dramática do seu estado geral e regressão dos tumores orbitais. Embora a presença de mais de uma lesão óssea separada na órbita geralmente sugira o diagnóstico de lesões metastáticas, nosso caso evidencia que tumores marrons devem também ser incluídos no diagnóstico diferencial, particularmente em pacientes com hiperparatireoidismo. 
Descritores: Hiperparatireoidismo secundário; Insuficiência renal crônica/complicações; Neoplasias orbitárias; Exoftalmia/etiologia; Transtornos da visão/etiologia; Diagnóstico diferencial; Relatos de caso [Tipo de publicação]

\section{REFERENCES}

1. Levine MR, Chu A, Abdul-Karim FW. Brown tumor and secondary hyperparathyroidism. Arch Ophthalmol. 1991;109(6):847-9.
2. Parrish CM, O'Day DM. Brown tumor of the orbit. Case report and review of the literature. Arch Ophthalmol. 1986;104(8):1199-202.

3. Zwick OM, Vagefi MR, Cockerham KP, McDermott MW. Brown tumor of secondary hyperparathyroidism involving the superior orbit and frontal calvarium. Ophthal Plast Reconstr Surg. 2006;22(4):304-6.

4. Naiman J, Green WR, d'Heurle D, Iliff WJ, Benedict GW, Eggleston JC, et al. Brown tumor of the orbit associated with primary hyperparathyroidism. Am J Ophthalmol. 1980;90(4):565-71.

5. Holzer NJ, Croft CB, Walsh JB, Naidich T, Zarday Z. Brown tumor of the orbit. JAMA. 1977;238(16):1758-9.

6. Park K, Mannor GE, Wolfley DE. Preoperative embolization of an orbital brown tumor. Am J Ophthalmol. 1994;117(5):679-80.

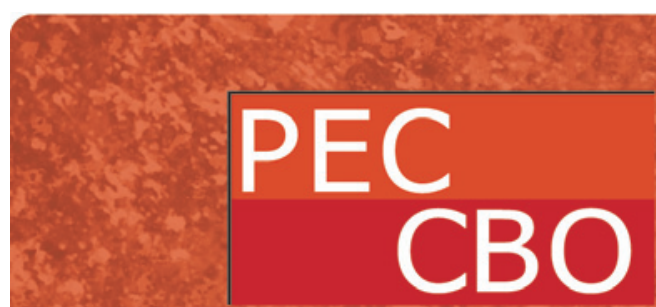

\section{Programa de Edurafóa Médica Gontinuada Dficial do Bonselho Brasileiru de Dftalmulagia}

